\title{
A review of gastrointestinal physiology and the mechanisms underlying the health benefits of dietary fiber: Matching an effective fiber with specific patient needs
}

\author{
Johnson W. McRorie ${ }^{1,2}$, George C. Fahey ${ }^{3}$ \\ 1. Procter \& Gamble, Mason, Ohio, U.S.A. 2. Mississippi State University, College of Veterinary Medicine, Starkville, \\ Mississippi, U.S.A. 3. University of Illinois Department of Animal Sciences, Urbana, Illinois, U.S.A.
}

Correspondence: Johnson W. McRorie. Address: Procter \& Gamble, Mason Business Center, 8700 Mason-Montgomery road, Mason, $\mathrm{OH} 45040$, U.S.A. Email: mcrorie.jw@pg.com

Received: July 10, 2013

DOI : $10.5430 /$ cns.v1n4p82
Accepted: September 12, 2013

URL: http://dx.doi.org/10.5430/cns.v1n4p82

\section{Abstract}

A primary function of the gastrointestinal tract is to provide the body with water, electrolytes and nutrients. It accomplishes this by ingestion, mechanical shearing, mixing and movement of the food through the gastrointestinal tract (motor events), secretion of digestive juices $(\approx 6$ liters per day) for degradation of complex nutrients into simple nutrients (e.g. complex carbohydrate into simple sugars), absorption of simple nutrients, water and electrolytes, and bacterial degradation of residue in the large bowel / elimination of waste. The small bowel is $\approx 7$ meters long with a mucosa that is studded with millions of villi (each with microvilli), giving the small bowel a surface area approximately the size of a tennis court. Most digestion/absorption normally occurs early in the proximal small bowel. Non-digested/absorbed chyme arrives as a liquid in the cecum, and, under normal conditions, is gradually dehydrated as it slowly passes through the large bowel until it is eliminated as formed stool. Different types of dietary fiber can exert specific mechanical effects on each of these gastrointestinal functions, which can lead to local benefits (e.g. relief of constipation) as well as systemic benefits (e.g. cholesterol lowering, improved glycemic control). Three characteristics of fiber (solubility, viscosity and fermentation) are predictive of the health benefits of different fiber types. Based on these three characteristics, dietary fiber can be divided into four clinically meaningful designations that support recommendations to address the specific healthcare needs of each patient. This review will describe the four clinically meaningful designations for dietary fiber, and provide a summary of the clinical studies that support the health benefits for each.

\section{Key words}

Fiber, Viscosity, Fermentation, Metabolic Syndrome, Diabetes

\section{I ntroduction}

The gastrointestinal (GI) tract is designed to provide the body with an essential and continual supply of water, electrolytes and nutrients. It accomplishes this via muscular contractions of the gut wall that mechanically shear food into smaller particles, mix food with gastric acid and digestive enzymes, and propel contents to the next region of the gut ${ }^{[1]}$. Nutrients 
and water are absorbed across the mucosa of the small bowel, which performs as both an absorptive membrane with a surface area representing the largest exposure to the outside world, and a barrier, forming the largest immune organ in the body ${ }^{[1]}$. Components of the diet that are not digested and absorbed in the small bowel are delivered to the large bowel, where further degradation can be facilitated by bacteria, which outnumber the cells in the human body by more than 10-to- ${ }^{[2]}$. The large bowel facilitates absorption of nutrients released by bacterial fermentation, and absorbs water, turning liquid digesta into formed stool ${ }^{[1]}$. All of these functions can be significantly affected by the physical characteristics of dietary fiber, including particle size and shape for insoluble fiber, and viscosity as well as extent/rate of fermentation for soluble fiber ${ }^{[3]}$.

\section{Four clinically meaningful designations for dietary fiber}

From the perspective of both GI physiology and therapeutic effect, dietary fiber can be thought of in four clinically meaningful categories based on three characteristics (solubility, fermentation and viscosity):

Table 1. Four clinically meaningful fiber designations

\begin{tabular}{|c|c|c|}
\hline Clinically meaningful designation & $\begin{array}{l}\text { Clinically demonstrated health } \\
\text { benefits }\end{array}$ & Representative fibers \\
\hline Insoluble & $\begin{array}{l}\text { Laxative effect (if particles are } \\
\text { sufficiently large, coarse) }\end{array}$ & $\begin{array}{l}\text { Wheat bran } \\
\text { Cellulose } \\
\text { Corn bran } \\
\text { Fruit fiber } \\
\text { Rice bran fiber }\end{array}$ \\
\hline $\begin{array}{l}\text { Soluble, non-viscous, readily } \\
\text { fermented }\end{array}$ & None at physiologic doses & $\begin{array}{l}\text { Wheat dextrin } \\
\text { Inulin } \\
\text { Oligosaccharides } \\
\alpha \text {-Cyclodextrin } \\
\text { Resistant maltodextrins } \\
\text { Polydextrose } \\
\text { Resistant starch } \\
\text { Soy fiber }\end{array}$ \\
\hline Soluble, viscous, readily fermented & $\begin{array}{l}\text { Cholesterol lowering } \\
\text { Improved glycemic control }\end{array}$ & $\begin{array}{l}\beta \text {-glucan (oats and barley) } \\
\text { Guar gum (raw, unhydrolyzed) } \\
\text { Glucomannan (Konjac) } \\
\text { Pectins } \\
\text { Gum arabic }\end{array}$ \\
\hline Soluble, viscous, non-fermented & $\begin{array}{l}\text { Cholesterol-lowering } \\
\text { Improved glycemic control } \\
\text { Stool normalization } \\
\text { Weight loss }\end{array}$ & Psyllium \\
\hline
\end{tabular}

1) Insoluble / poorly fermented (e.g. wheat bran): not dissolved in water, poorly fermented, exerts a laxative effect by mechanical irritation/stimulation of gut mucosa if particles are sufficiently large and coarse. Small smooth particles (e.g. wheat bran flour/bread) have no laxative efficacy;

2) Soluble non-viscous / readily fermented (e.g. inulin, oligosaccharides, resistant starches, wheat dextrin): dissolves in water, no significant increase in viscosity (no cholesterol lowering or improved glycemic control benefit), rapidly fermented, (rapid gas formation, energy harvest [calorie uptake] from fermentation by-products), may be considered a prebiotic if an associated clinical benefit is demonstrated; 
3) Soluble viscous / readily fermented (e.g. $\beta$-glucan, guar gum, gum Arabic, karaya gum): increased chyme viscosity improves glycemic control by slowing carbohydrate degradation and glucose absorption, delivering nutrients to the distal ileum to stimulate mucosal L-cells to release metabolically active peptides [e.g. glucagon-like peptide-1 (GLP-1)]; viscous chyme also captures and eliminates bile, stimulating bile production, resulting in lower serum cholesterol; readily fermented by colonic bacteria (gas formation, energy harvest from fermentation by-products);

4) Soluble viscous / non-fermented (e.g. psyllium): increased chyme viscosity drives improved glycemic control and cholesterol lowering as above, but the lack of fermentation results in no appreciable calorie harvest from fermentation by-products, and the viscous gel remains intact throughout the large bowel, driving a stool normalizing effect (softens hard stool in constipation, firms loose/liquid stool in diarrhea).

The following sections will describe how the physical characteristics of fiber affect the function of each region of the gastrointestinal tract and the resulting therapeutic effects, with a focus on viscous fiber. A listing of example fibers found in each of the four clinically meaningful designations for fiber can be found in Table 1.

\section{Esophagus}

Swallowing begins as a voluntary function, where the tongue moves a bolus of food up and back against the palate and into the pharynx. From this point on, swallowing becomes automatic, and has the potential to become complicated ${ }^{[1]}$. The food bolus is pushed back into the pharynx, which is primarily involved in respiration but momentarily becomes a pathway for swallowing. As the food bolus reaches the pharynx, it stimulates the swallowing reflex, which initiates a sequence of events: 1) the soft palate is pulled upward, preventing food/liquids from entering the nasal cavities, 2) the palatepharyngeal folds are briefly $(<1 \mathrm{~s})$ pulled toward the midline, forming a narrow slit that restricts the size of the bolus that can enter the esophagus, 3 ) the vocal cords and larynx pull together, and the epiglottis swings back, all of which prevents the bolus from entering the airway (nose and trachea), 4) the bolus enters the esophagus through a relaxed upper esophageal sphincter, which closes again once the bolus is past, preventing air from entering the esophagus during respiration, 5) a primary peristaltic wave propels the bolus the length of the esophagus (5-8 s), 6) the lower esophageal sphincter relaxes to allow the bolus to enter the stomach, then contracts again to keep stomach contents from refluxing back into the esophagus ${ }^{[1]}$. Disruption of this highly coordinated process (e.g. dysphagia secondary to stroke) can lead to liquids and food particles entering the airway and lungs (aspiration), potentially causing choking and pneumonia. Highly viscous soluble fiber can be used to thicken and form a cohesive gel-matrix in a concentration-dependent manner when hydrated, increasing bolus viscosity and cohesion and facilitating passage of an intact bolus. This reduces the risk of aspiration ${ }^{[4,5]}$.

\section{Stomach}

The stomach is divided into 4 anatomical regions (cardiac, fundus, corpus and pyloric antrum), but functionally the stomach has two regions [proximal (storage) and distal (antral pump) ${ }^{[1]}$. The proximal portion of the stomach has rugae (accordion-like folds) when empty that relax and stretch to accommodate meals. Tonic contractions of the proximal stomach gradually force food into the distal portion of the stomach, where rugae give way to a smooth-walled muscular antrum. The antrum has repeating aborad waves of contraction referred to as the "antral pump". These phasic waves of contraction drive discreet boluses of liquids and small particles into the small bowel through the pyloric sphincter when it is open (1-2 mm) at the beginning of each wave, but when the pyloric sphincter closes midway through each contraction, the contents trapped between the closed sphincter and the contraction are forced back through the ring of contraction. This back-extrusion is responsible for mixing stomach contents with gastric acid and pepsin, and grinding large pieces into small particles. The rate of gastric emptying is controlled by several factors, including caloric density (low calorie digesta empties faster than high calorie) and meal composition (liquids empty faster than solids) ${ }^{[6-8]}$. The data on the effects of 
viscous fibers on gastric emptying are mixed, but the discrepancy is most likely due to the methods used to assess gastric emptying. When added to a liquid test meal, viscous soluble fiber slows the rate of gastric emptying due to increased viscosity. When added to a solid test meal, viscous soluble fiber can increase the rate of gastric emptying by decreasing the viscosity of the solids.

\section{Small intestine}

The small intestine is $\approx 7$ meters long and divided anatomically into three main regions: duodenum, jejunum and ileum. The mucosa of the small intestine is studded with millions of villi, each covered with $\approx 1,000$ microvilli per 0.1 micron $^{2}$ (known as the brush border), making the small intestine the largest body surface exposed to the outside world (approximately 250 square meters, roughly the size of a tennis court), and the largest immune organ in the body ${ }^{[1]}$. Delivery of acidic nutrients into the duodenum (proximal small bowel) stimulates gall bladder contraction (release of bile) and pancreatic secretion (inorganic $=$ water, bicarbonate and electrolytes; organic $=$ digestive enzymes). The total quantity of fluid absorbed by the small bowel each day is a combination of fluids consumed $(\approx 1.5$ liters per day) and the digestive juices secreted ( $\approx 6$ to 7 liters per day). Motor events in a fed state are predominantly segmental mixing waves, which mix chyme for exposure to digestive enzymes and to the absorptive brush border of the mucosa ${ }^{[1]}$. Due to the large surface area and the low viscosity of chyme, digestion/absorption normally occurs early in the proximal small bowel.

Introduction of a viscous soluble fiber increases the viscosity of chyme, which slows the mixing of chyme, slows the interactions of digestive enzymes with nutrients, and slows the degradation of complex nutrients to absorbable components, all of which slows the absorption of glucose and other nutrients ${ }^{[3]}$. This slowing of nutrient degradation and absorption delivers nutrients to more distal regions of the small bowel (e.g. distal ileum), where nutrients are not normally present, stimulating mucosal receptors to initiate several metabolic responses. One of these responses is the release of GLP-1 into the blood stream, a short lived ( $\approx 2$-minute half-life) peptide that decreases appetite, increases insulin secretion, decreases glucagon-secretion [peptide that stimulates glucose production (gluconeogenesis) primarily in the liver], increases pancreatic $\beta$-cell growth (cells that produce insulin), improves insulin production and sensitivity, and slows gastric emptying and small bowel transit ("ileal brake" phenomenon), all of which leads to improved glycemic control in type 2 diabetes ${ }^{[3,8-15]}$. It has been established for over 3 decades that the viscosity of a dietary fiber is highly correlated with reducing postprandial glucose and insulin serum concentrations. In a study published over 3 decades ago ${ }^{[16]}$, volunteers underwent 50-g glucose tolerance tests with and without the addition of several dietary fibers, including guar gum, a highly viscous (gel-forming) fiber. High viscosity native guar gum was effective for flattening the glucose response, but this effect was abolished when the guar gum was hydrolyzed (non-viscous). The study further showed that a reduction in mean peak rise in blood glucose was highly correlated with viscosity $(\mathrm{r}=0.926 ; P<0.01)$ and a delay in mouth-to-cecum transit time $(\mathrm{r}=0.885 ; P<0.02)$.

Numerous multi-week clinical studies have demonstrated consumption of a viscous soluble fiber supplement (e.g. psyllium) before meals improves glycemic control (lower fasting blood glucose, insulin and HbA1c concentrations) in subjects at risk for type 2 diabetes (e.g. metabolic syndrome) and patients being treated for type 2 diabetes ${ }^{[17-33]}$. It is important to note that consumption of viscous fiber will not cause blood glucose concentrations to drop below normal limits (hypoglycemia), because the suppression of glucagon by GLP-1 does not occur at hypoglycemic levels. When considered across studies, the effects of viscous fiber (e.g. psyllium) on glycemic control are a function of a subject's baseline glycemic control: the higher the baseline value for fasting blood glucose concentration, the greater the clinical benefit of viscous fiber: no significant effect on normal blood glucose concentrations in healthy subjects with normal glycemic control ${ }^{[17-20]}$, a moderate effect in patients with pre-diabetes / metabolic syndrome [e.g. $-19.8 \mathrm{mg} / \mathrm{dL}$ for psyllium $3.5 \mathrm{~g}$ bid; $-9 \mathrm{mg} / \mathrm{dL}$ for guar gum $3.5 \mathrm{~g}$ bid ${ }^{[21]}$ ] and a larger effect in patients with type 2 diabetes [e.g. psyllium, $-35.0 \mathrm{mg} / \mathrm{dL}^{[27]}$ to $-89.7 \mathrm{mg} / \mathrm{dL}^{[22]}$. Note that the glycemic benefit of psyllium in patients with type 2 diabetes is in addition to the effects already conveyed by prescription drugs to treat hyperglycemia. Note that it is important to monitor blood glucose concentrations when starting an effective fiber therapy, as it may decrease the required doses of 
hypoglycemic drugs. Taken together, these data support that the clinical benefit of a viscous soluble fiber is proportional to loss of glycemic control: no significant effect on blood glucose in healthy subjects, a modest effect in pre-diabetes, and a larger effect in type 2 diabetes. Further, the data support a role for viscous soluble fiber in health maintenance: when taken before each meal, viscous soluble fiber can help maintain healthier blood glucose concentrations, thereby reducing the risks associated with chronically elevated blood glucose levels.

Viscous soluble fiber also can trap and eliminate bile. Bile is secreted by the liver (normally $600-1,000 \mathrm{~mL}$ per day) to emulsify large fat particles into many small particles for digestion by lipase enzymes and absorption across the mucosa ${ }^{[1]}$. Bile is normally recovered in the distal ileum and recycled, potentially several times within a single meal. When bile is captured by a viscous soluble fiber and eliminated via stool, the liver must produce more bile. Cholesterol is a component of bile, and the liver uses serum stores of cholesterol to generate more bile, effectively lowering LDL and total serum cholesterol without affecting HDL cholesterol ${ }^{[34]}$. As with glycemic control, the viscosity of a soluble fiber is a better predictor of efficacy for cholesterol lowering than quantity of fiber ${ }^{[17]}$. A PubMed search of the terms 'psyllium' and 'cholesterol' yielded 160 published articles, of which 21 were randomized, well-controlled clinical studies (totaling 1,568 subjects) that assessed the efficacy of psyllium (6-15 g/day; most studies $10 \mathrm{~g} /$ day) for lowering serum cholesterol ${ }^{[18,20,21,27,28,35-50]}$. Overall, these 21 studies show that total cholesterol was decreased $2 \%$ to $20 \%$ versus placebo, and LDL-cholesterol was decreased $6 \%$ to $24 \%$ versus placebo. As with glycemic control, the magnitude of the observed benefit of psyllium on cholesterol concentration was a function of a subject's baseline cholesterol concentration: the higher the baseline cholesterol concentration, the greater the effect of psyllium for lowering serum cholesterol. Several studies have also explored psyllium as a co-therapy with statin drugs, and found that there is a significant cholesterol lowering benefit with psyllium beyond that provided by the statins ${ }^{[51-53]}$. Further, a low dose statin (simvastatin $10 \mathrm{mg}$ ) plus psyllium ( $15 \mathrm{~g} /$ day $)$ provided significantly better LDL-cholesterol lowering $(-63 \mathrm{mg} / \mathrm{dL})$ than a high dose of simvastatin alone $(20 \mathrm{mg},-55 \mathrm{mg} / \mathrm{dL}, p=0.03)^{[53]}$.

According to the International Diabetes Federation, Metabolic Syndrome is defined as a cluster of the most dangerous heart attack risk factors: diabetes and raised fasting plasma glucose, abdominal obesity, high cholesterol and high blood pressure ${ }^{[54]}$. The Federation also states that people with metabolic syndrome: are twice as likely to die from, and three times as likely to have a heart attack or stroke compared with patients without the syndrome, and have a five-fold greater risk of developing type 2 diabetes ${ }^{[54]}$. The Federation estimates that $1 / 4$ of adults worldwide have Metabolic Syndrome ${ }^{[54]}$. A 6-month study conducted in Italy assessed the clinical benefits of two soluble viscous fibers in 141 patients with metabolic syndrome ${ }^{[21]}$. In this randomized, controlled clinical study, patients were fed an American Heart Association step-2 diet alone, or the same diet supplemented with psyllium or guar gum ( $3.5 \mathrm{~g}$ twice a day with breakfast and dinner). After 6 months of treatment, both psyllium and guar gum showed significant improvement in body mass index (BMI:- $7.2 \%$ vs. $-6.5 \%)$, fasting plasma glucose (-27.9\% vs. $-11.1 \%)$ and insulin $(-20.4 \%$ vs. $-10.8 \%)$, HbA1c $(-10.4 \%$ vs. $-10.3 \%)$, and low-density lipoprotein (LDL) cholesterol $(-7.9 \%$ vs. $-8.5 \%)$, respectively. Only the psyllium supplementation exerted a significant improvement in plasma triglyceride concentration (-13.3\%) and systolic (-3.9\%) and diastolic blood pressure (-2.6\%). After 2 months, the guar gum (readily fermented) treatment group showed a marked weight reduction (-2.4 $\mathrm{kg}$ versus baseline), but this changed to weight re-gain over the following 4 months (see Figure 1). In contrast, the psyllium (non-fermented) treatment group showed gradual and continued weight loss across the 6 month test period. At 6 months, weight loss for the psyllium treatment group was $-3.3 \mathrm{~kg}$ versus baseline, $-2.1 \mathrm{~kg}$ versus placebo, and $-1.76 \mathrm{~kg}$ versus guar gum ( $p<0.01$ for all 3 comparisons; Figure 1). At the conclusion of the study, $12.5 \%$ of patients in the psyllium group no longer qualified for a diagnosis of Metabolic Syndrome, versus $2.1 \%$ of patients in the guar gum group and $0 \%$ of patients in the diet-alone group ${ }^{[21]}$. Patients who are overweight or obese are at high risk for developing Metabolic Syndrome and Type 2 Diabetes Mellitus. When recommending a high fiber diet to facilitate weight loss, the fermentation characteristics of each fiber type should be taken into consideration. 


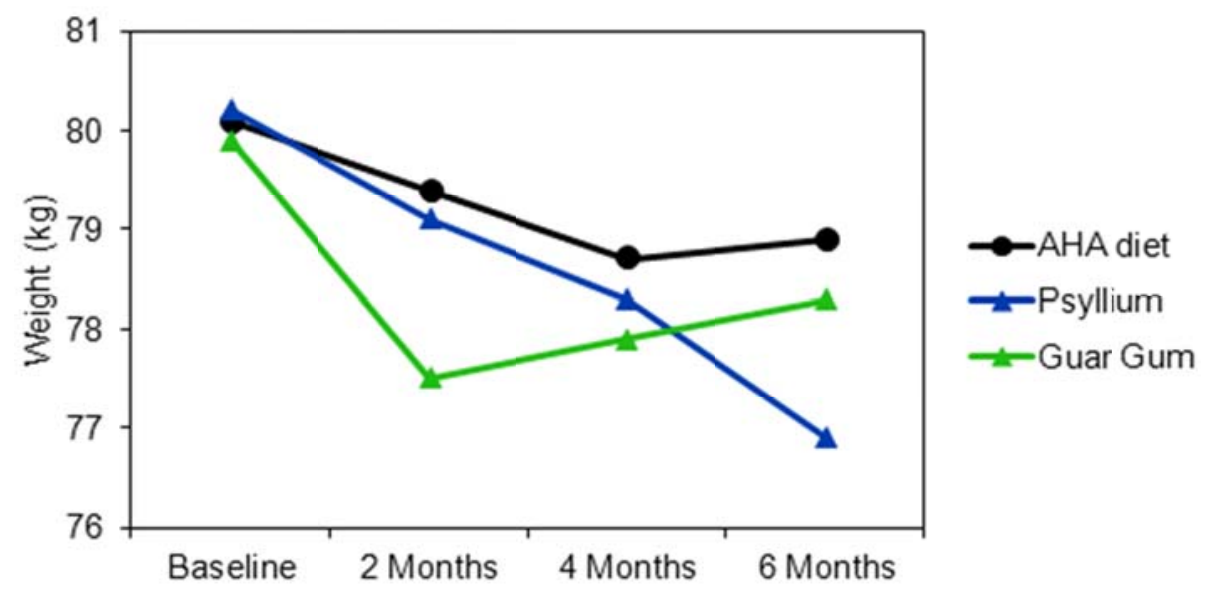

Figure 1. Sustained Weight Loss versus Weight Re-Gain While Maintaining a Healthy, High Fiber Diet - A Function of Fermentation?

In a 6-month study in 141 patients with Metabolic Syndrome, all patients were on a restricted American Heart Association (AHA) step-2 diet. Additionally, two groups added either guar gum (3.5g bid) or psyllium $(3.5 \mathrm{~g}$ bid) to the diet. The guar gum (readily fermentable) group showed significant weight loss at 2 months, followed by weight re-gain. In contrast, the psyllium (non-fermentable) group showed more gradual but sustained weight loss across 6 months of dosing. At 6 months, weight loss for the psyllium treatment group was $-3.3 \mathrm{~kg}$ versus baseline, $-2.1 \mathrm{~kg}$ versus placebo, and $-1.76 \mathrm{~kg}$ versus guar gum ( $<<0.01$ for all 3 comparisons) ${ }^{[21]}$.

\section{Large intestine}

The large intestine is comprised of the cecum (most proximal portion, receives liquid chyme from ileum), the colon (ascending, transverse, descending and sigmoid), the rectum and the anus. Approximately 1,500 $\mathrm{mL}$ of liquid chyme arrives in the large intestine daily ${ }^{[1]}$. Normally, over $90 \%$ of the water and electrolytes are absorbed by the large intestine, resulting in formed stool. The motor events of the large intestine are $\approx 95 \%$ segmental ("mixing" waves) allowing for water and electrolyte absorption, while the remaining $\approx 5 \%$ are propagating contractions (peristalsis) ${ }^{[55-58]}$. Propagating contractions in the large bowel occur across a wide range of amplitudes and propagating rates, and amplitude is inversely proportional to propagating rate (high amplitude contraction $=$ slow propagation rate; low amplitude contraction $=$ fast propagation rate), and propagating rate is proportional to event frequency (slow propagation rate = few events per day; fast propagation rate $=$ many events per day $)^{[55-58]}$. At one extreme, high amplitude $(>100 \mathrm{mmHg})$, slowly propagating $(0.5-1$ $\mathrm{cm} / \mathrm{s}$ ) contractions are infrequent ( $<6$ per day) lumen-occluding events that propel all large bowel contents (gas, liquids, soft to hard stool) ${ }^{[3,55-58]}$. At the other extreme, low amplitude $(10 \mathrm{~mm} \mathrm{Hg})$, rapidly propagating $(>10 \mathrm{~cm} / \mathrm{s})$ contractions are frequent events (>30/day) that propel only gas ${ }^{[55,58]}$. There are 'medium amplitude and propagating rate' contractions that populate the middle of the range ${ }^{[55]}$.

When considered in light of the different viscosities present in the large bowel (e.g. gas, liquid/loose/soft/formed/hard stool), the rate of transit through the large intestine is a function of the frequency and amplitude/rate of propagating contractions versus the viscosity of the substrate. For example, gas is propelled by all propagating contractions, from infrequent high amplitude slowly propagating contractions to frequent low amplitude rapidly propagating contractions, making gas the most rapidly propelled substrate in the gut. Gas can transit the entire gastrointestinal tract in less than an hour (flatulence $\approx 14$ episodes/day) ${ }^{[55]}$. Liquid stool is propelled by all but the smallest/fastest propagating contractions (gas only), resulting in rapid transit through the large bowel (e.g. diarrhea) and the potential for multiple bowel movements a day ${ }^{[59]}$. In contrast, formed or hard stool is only propelled by infrequent high amplitude slowly propagating contractions, and transit through the large bowel can require days $\left(\approx 1\right.$ bowel movement/day ${ }^{[3,55-58]}$. This is why a fiber that exerts a 
significant stool softening (water-holding) effect can result in faster transit and more frequent bowel movements, which provides clinical relief from constipation.

Insoluble fiber, which does not dissolve in water and has no water-holding capacity, exerts a mechanical stimulatory effect on the gut mucosa that increases water/mucous secretion (stool softening) and propagating contractions (faster transit) proportional to the size and shape (rough versus smooth) of the insoluble particles ${ }^{[60-62]}$. Studies comparing the laxative effects of wheat bran, milled to specific particle sizes, to plastic particles, cut to match the particle size of the wheat bran, showed that large/coarse particles had a significant laxative effect while small/smooth particles had no laxative effect ${ }^{\left[{ }^{[0-62]}\right.}$. For wheat bran to exert a laxative effect, it must be coarse milled with large/rough particles. Soluble fiber that is non-viscous (e.g. wheat dextrin, inulin) dissolves in water with no appreciable change to viscosity (does not gel), and is rapidly fermented in the large bowel, resulting in significant gas production but no significant laxative benefit ${ }^{[3]}$. A viscous soluble fiber that is readily fermented (e.g. $\beta$-glucan, guar gum) will also result in significant gas formation, but loses its viscosity/water-holding capacity during fermentation, resulting in a negligible laxative effect at physiological doses ${ }^{[3,63]}$. In contrast, a non-fermented ${ }^{[64]}$ (no gas formation) viscous soluble fiber (e.g. psyllium) that maintains its viscosity/water holding capacity throughout the large bowel ${ }^{[65]}$ can have a dichotomous, 'stool normalizing' effect: decreasing the viscosity of hard stool in constipation (softer stool, increased transit rate, improved bowel movement frequency), and increasing the viscosity of loose/liquid stool in diarrhea (firmer stool, slower transit rate, less frequent bowel movements) ${ }^{[3,66-68]}$. The gel-forming, water-holding capacity of psyllium has been shown to soften hard stool better than docusate, a marketed stool softener ${ }^{[59]}$, and to firm loose/liquid stool in diarrhea, normalizing stool form ${ }^{[66-68]}$. The stool normalizing benefit (e.g. psyllium) also has been shown to be an effective co-therapy in normalizing stool form and improving satisfaction with bowel habits in patients with Irritable Bowel Syndrome ${ }^{[67,69]}$.

\section{Discomfort associated with new/ increased fiber regimen}

Sensations ranging from mild discomfort to cramping pain, which can be associated with new/increased intake of dietary fiber, are viscosity-related events associated with an objective measure of stool viscosity, the "stool viscosity ratio" (SVR): highest stool viscosity divided by lowest stool viscosity within 24 hours ${ }^{[59]}$. A high amplitude propagating contraction that propels soft stool against more distal firm/hard stool can result in acute bowel wall distention (soft stool causes bowel wall to 'balloon' out), stimulating circumferential mechanoreceptors and causing discomfort/pain (much like balloon distention of the bowel wall in studies of pain threshold in patients with irritable bowel syndrome) ${ }^{[3,59]}$. Gradually introducing fiber to the diet can normalize stool form and minimize the risk of discomfort that can be associated with increased fiber intake. A more detailed description of this phenomenon, including figures of bowel wall distention, is provided in a previous review ${ }^{[3]}$.

\section{Conclusions}

Based on three fiber characteristics (solubility, viscosity and fermentation), there are four clinically meaningful designations for dietary fiber:

1) Insoluble, poorly fermented (laxative benefit if particles are sufficiently large/coarse),

2) Soluble non-viscous, readily fermented (no clinically proven health benefits at physiologic doses),

3) Soluble viscous, readily fermented (cholesterol lowering, glycemic benefit), and

4) Soluble viscous, non-fermented (cholesterol lowering, glycemic benefit, stool normalizer: softens hard stool to relieve constipation, firms loose/liquid stool to relieve diarrhea). The magnitude of the health benefit associated with soluble fiber is proportional to both the viscosity of the soluble fiber and the baseline clinical value (e.g. cholesterol, fasting blood 
sugar): normal values are not significantly altered, but as clinical values increase above normal limits, the magnitude of the observed health benefit also increases. Taken together, these data support a role for insoluble fiber in constipation, and viscous soluble fiber as an effective co-therapy in Metabolic Syndrome and Type 2 Diabetes Mellitus. Additionally, if the viscous soluble fiber is not fermented, the intact gel can also normalize stool form to relieve both constipation and diarrhea, which can be particularly beneficial when treating the fluctuating bowel habits exhibited by patients with Irritable Bowel Syndrome.

\section{References}

[1] Guyton A, Hall J. Textbook of Medical Physiology, 11th edition, 2006, Elsevier Inc., Philadelphia, PA, Unit XII, Chapters 62-66.

[2] R. E. Ley, D. A. Peterson, and J. I. Gordon, "Ecological and evolutionary forces shaping microbial diversity in the human intestine," Cell, 2006; 124 (4): 837-848. PMid:16497592 http://dx.doi.org/10.1016/j.cell.2006.02.017

[3] Chutkan R, Fahey G, Wright W, McRorie J. Viscous versus non-viscous soluble fiber supplements: Mechanisms and evidence for fiber-specific health benefits. J Am Acad Nurse Pract. 2012; 24: 476-487. PMid:22845031 http://dx.doi.org/10.1111/j.1745-7599.2012.00758.x

[4] Seo C, Yoo B. Steady and Dynamic Shear Rheological Properties of Gum-Based Food Thickeners Used for Diet Modification of Patients with Dysphagia: Effect of Concentration. Dysphagia. 2013; 28: 205-211. PMid:23179025 http://dx.doi.org/10.1007/s00455-012-9433-x

[5] O'Leary M, Hanson B, Smith C. Viscosity and non-Newtonian features of thickened fluids used for dysphagia therapy. J Food Sci. 2010; 75: E330-338. PMid:20722917 http://dx.doi.org/10.1111/j.1750-3841.2010.01673.x

[6] Lobo D, Hendry P, Rodrigues G, Marciani L, Totman J, Wright J, Preston T, Gowland P, Spiller R, Fearon K. Gastric emptying of three liquid oral preoperative metabolic preconditioning regimens measured by magnetic resonance imaging in healthy adult volunteers: a randomised double-blind, crossover study. Clin Nutr. 2009; 28: 636-641.PMid:19500889 http://dx.doi.org/10.1016/j.clnu.2009.05.002

[7] Shimoyama Y, Kusano M, Kawamura O, Zai H, Kuribayashi S, Higuchi T, Nagoshi A, Maeda M, Mori M. High-viscosity liquid meal accelerates gastric emptying. Neurogastroenterol Motil. 2007; 19: 879-886. PMid:17973639 http://dx.doi.org/10.1111/j.1365-2982.2007.00972.x

[8] Dikeman C, Fahey G. Viscosity as related to dietary fiber: a review. Crit Rev Food Sci Nutr. 2006; 46: 649-663. PMid:17092830 http://dx.doi.org/10.1080/10408390500511862

[9] Schirra J, Goke B. The physiological role of GLP-1 in human: incretin, ileal brake or more? Regul Pept. 2005; 128: $109-115$. PMid:15780430 http://dx.doi.org/10.1016/j.regpep.2004.06.018

[10] Dikeman C, Murphy M, Fahey G. Dietary fibers affect viscosity of solutions and simulated human gastric and small intestine digesta, J of Nutr. 2006; 136: 913-919. PMid:16549450

[11] Jenkins D, Wolever T, Taylor R, Barker H, Fielden H, Baldwin J, Bowling A, Newman H, Jenkins A, Goff D. Glycemic index of foods: a physiological basis for carbohydrate exchange. Am J Clin Nutr. 1981; 34: 362 -366. PMid:6259925

[12] Wolever T, Jenkins D. The use of the glycemic index in predicting the blood glucose response to mixed meals. Am J Clin Nutr. 1986; 43: 167-172. PMid:3942088

[13] Maljaars P, Peters H, Mela D, Masclee A. Ileal brake: a sensible food target for appetite control. A review. Physiol Behav. 2008;95: 271-281. PMid:18692080 http://dx.doi.org/10.1016/j.physbeh.2008.07.018

[14] Holst J, Deacon C, Vilsbøll T, Krarup T, Madsbad S. Glucagon-like peptide-1, glucose homeostasis and diabetes. Trends Mol Med. 2008;14:161-168. PMid:18353723 http://dx.doi.org/10.1016/j.molmed.2008.01.003

[15] Maljaars P, Peters H, Kodde A, Geraedts M, Troost F, Haddeman E, Masclee A. Length and site of the small intestine exposed to fat influences hunger and food intake. Br J Nutr. 2011; 106: 1609-1615. PMid:21736790 http://dx.doi.org/10.1017/S0007114511002054

[16] Jenkins D, Wolever T, Leeds A, Gassull M, Haisman P, Dilawari J, Goff D, Metz GL, Alberti K. Dietary fibres, fibre analogues, and glucose tolerance: importance of viscosity. Br Med J. 1978; 1: 1392-1394. PMid:647304 http://dx.doi.org/10.1136/bmj.1.6124.1392

[17] Vuksan V, Jenkins AL, Rogovik AL, Fairgrieve CD, Jovanovski E, Leiter LA. Viscosity rather than quantity of dietary fibre predicts cholesterol-lowering effect in healthy individuals. Br J Nutr. 2011 Nov; 106: 1349-1352. PMid:21736815 http://dx.doi.org/10.1017/S0007114511001711 
[18] Anderson J, Zettwoch N, Feldman T, Tietyen-Clark J, Oeltgen P, Bishop C. Cholesterol-lowering effects of psyllium hydrophilic mucilloid for hypercholetserolemic men. Arch Intern Med. 1988; 148: 292-296. PMid:3277558 http://dx.doi.org/10.1001/archinte.1988.00380020036007

[19] Neal G, Balm T. Synergistic effects of psyllium in the dietary treatment of hypercholesterolemia. South Med J. 1990; 83: 1131-1137. PMid:2218650 http://dx.doi.org/10.1097/00007611-199010000-00005

[20] Gupta RR, Agrawal CG, Singh GP, Ghatak A. Lipid-lowering efficacy of psyllium hydrophilic mucilloid in non-insulin dependent diabetes mellitus with hyperlipidemia. Indian J Med Res. 1994; 100: 237-241. PMid:7829159

[21] Cicero AFG, Derosa G, Bove M, Imola F, Borghi C, Gaddi AV. Psyllium improves dyslipidemaemia, hyperglycaemia and hypertension, while guar gum reduces body weight more rapidly in patients affected by metabolic syndrome following an AHA Step 2 diet. Mediterr J Nutr Metab. 2010;3:47-54. http://dx.doi.org/10.1007/s12349-009-0056-1

[22] Ziai S, Larijani B, Akhoondzadeh S, Fakhzadeh H, Dastpak A, Bandarian F, et al. Psyllium decreased serum glucose and glycosylated hemoglobin significantly in diabetic outpatients. J Ethnopharmacol. 2005; 102: 202-207. PMid:16154305 http://dx.doi.org/10.1016/j.jep.2005.06.042

[23] Sartore G, Carlström S, Scherstén B. Dietary supplementation of fibre (Lunelax) as a means to reduce postprandial glucose in diabetics. Acta Med Scand Suppl. 1981; 656: 51-53.

[24] Jarjis H, Blackburn N, Redfern J, Read N. The effect of ispaghula (Fybogel and Metamucil) and guar gum on glucose tolerance in man. Br J Nutr. 1984; 51:371-378. PMid:6326798 http://dx.doi.org/10.1079/BJN19840043

[25] Wolever T, Vuksan V, Eshuis H, Spadafora P, Peterson R, Chao E, Storey M, Jenkins D. Effect of method of administration of psyllium on glycemic response and carbohydrate digestibility. J Am Coll Nutr. 1991; 10: 364-371. PMid:1654354 http://dx.doi.org/10.1080/07315724.1991.10718164

[26] Frati Munari A, Benitez Pinto W, Raul Ariza Andraca C, Casarrubias M. Lowering glycemic index of food by acarbose and plantago psyllium mucilage. Arch Med Res, 1998; 29: 137-141. PMid:9650328

[27] Rodriguez-Moran M, Guerrero-Romero F, Laczano-Burciaga L. Lipid- and glucose-lowering efficacy of plantago psyllium in type II diabetes. J Diabetes Complicat. 1998; 12: 273-278. http://dx.doi.org/10.1016/S1056-8727(98)00003-8

[28] Anderson J, Allgood L, Turner C, Oelgten P, Daggy B. Effects of psyllium on glucose and serum lipid responses in men with type 2 diabetes and hypercholesterolemia. Am J Clin Nutr. 1999; 70: 466-473. PMid:10500014

[29] Rigaud D, Paycha F, Meulemans A, Merrouche M, Mignon M. Effect of psyllium on gastric emptying, hunger feeling and food intake in normal volunteers: a double blind study. Eur J Clin Nutr. 1998; 52: 239-245. PMid:9578335 http://dx.doi.org/10.1038/sj.ejen.1600518

[30] Karhunen L, Juvonen K, Flander S, Liukkonen K, Lähteenmäki L, Siloaho M, Laaksonen D, Herzig K, Uusitupa M, Poutanen K. A psyllium fiber-enriched meal strongly attenuates postprandial gastrointestinal peptide release in healthy young adults. J Nutr. 2010; 140:737-744. PMid:20147463 http://dx.doi.org/10.3945/jn.109.115436

[31] Frost G, Brynes A, Dhillo W, Bloom S, McBurney M. The effects of fiber enrichment of pasta and fat content on gastric emptying, GLP-1, glucose, and insulin responses to a meal. Eur J Clin Nutr. 2003; 57: 293-8. PMid:12571662 http://dx.doi.org/10.1038/sj.ejcn.1601520

[32] Sierra M, Garcia J, Fernandez N, Diez M, Calle AP, Sahagun A. Effects of ispaghula husk and guar gum on postprandial glucose and insulin concentrations in healthy subjects. Eur J Clin Nutr. 2001; 55: 235-243. PMid:11360127 http://dx.doi.org/10.1038/sj.ejcn.1601147

[33] Feinglos, M., Gibb, R., Ramsey, D., Surwit, R. and McRorie, J. Psyllium improves glycemic control in patients with type-2 diabetes mellitus. Bioactive Carbohydrates and Dietary Fibre. 2013; 1: 156-161. http://dx.doi.org/10.1016/j.bcdf.2013.02.003

[34] Gunness P, Gidley MJ. Mechanisms underlying the cholesterol-lowering properties of soluble dietary fibre polysaccharides.Food Funct. 2010;1:149-155. PMid:21776465 http://dx.doi.org/10.1039/c0fo00080a

[35] Jenkins D, Wolever T, Vidgen E, Kendall C, Ransom T, Mehling C, Mueller S, Cunnane S, O'Connell N, Setchell K, Lau H, Teitel J, Garvey M, Fulgoni V, Connelly P, Patten R, Corey P. Effect of psyllium in hypercholesterolemia at two monounsaturated fatty acid intakes. Am J Clin Nutr.1997; 65: 1524-1533. PMid:9129487

[36] Anderson J, Floore T, Geil P. Hypocholesterolemic effects of different bulk-forming hydrophilic fibers as adjuncts to dietary therapy in mild to moderate hypercholesterolemia. Arch Intern Med. 1991; 151: 1597-1602. PMid:1872664 http://dx.doi.org/10.1001/archinte.1991.00400080089017

[37] Everson G, Daggy B, McKinley C, Story J. Effects of psyllium hydrophilic mucilloid on LDL-cholesterol and bile acid synthesis in hypercholesterolemic men. J Lipid Res. 1992; 33: 1183-1192. PMid:1431597

[38] Levin E, Miller V, Muesing R, Stoy D, Balm T, LaRosa J. Comparison of psyllium hydrophilic mucilloid and cellulose as adjuncts to a prudent diet in the treatment of mild to moderate hypercholesterolemia. Arch Intern Med.1990; 150: 1822-1827. PMid:2203322 http://dx.doi.org/10.1001/archinte.1990.00390200036007 
[39] Anderson J, Allgood L, Lawrence A. Cholesterol-lowering effects of psyllium intake adjunctive to diet therapy in men and women with hypercholesterolemia: meta-analysis of 8 controlled trials. Am J Clin Nutr. 2000; 71: 1433-1438. PMid:10837282

[40] Wolever T, Jenkins D, Mueller S, Boctor D, Ransom T, Patten R, et al. Method of administration influences the serum cholesterol-lowering effect of psyllium. Am J Clin Nutr. 1994(a); 59: 1055-1059.

[41] Stoy D, LaRosa J, Brewer B. Cholesterol-lowering effects of ready-to-eat cereal containing psyllium. J Am Diet Assoc. 1993; 93: 910-912. http://dx.doi.org/10.1016/0002-8223(93)91533-V

[42] Wolever T, Jenkins D, Mueller S, Patten R, Relle L, Boctor D, et al. Psyllium reduces blood lipids in men and women with hyperlipidemia. Am J Med Sci. 1994(b); 307: 269-273.

[43] Sprecher D, Harris B, Goldberg A. Efficacy of psyllium in reducing serum cholesterol levels in hypercholesterolemic patients on high- or low-fat diets. Ann Intern Med. 1993; 199: 545-554. http://dx.doi.org/10.7326/0003-4819-119-7_Part_1-199310010-00001

[44] Summerbell C, Manley P, Barnes D, Leeds A. The effects of psyllium on blood lipids in hypercholesterolaemic subjects. J Hum Nutr Diet. 1994; 7: 147-151. http://dx.doi.org/10.1111/j.1365-277X.1994.tb00423.x

[45] Bell L, Hectorne K, Reynolds H, Balm T, Hunninghake D. Cholesterol-lowering effects of psyllium hydrophilic mucilloid. Adjunct therapy to a prudent diet for patients with mild to moderate hypercholesterolemia. JAMA.1989; 261: 3419-3423. PMid:2724486 http://dx.doi.org/10.1001/jama.1989.03420230073029

[46] Bell L, Hectorn K, Reynolds H, Hunninghake D. Cholesterol-lowering effects of soluble-fiber cereals as part of a prudent diet for patients with mild to moderate hypercholesterolemia. Am J Clin Nutr. 1990; 52: 1020-1026. PMid:2173390

[47] Weingand K, Le N, Kuzmak B. Effects of psyllium on cholesterol and low-density lipoprotein metabolism in subjects with hypercholesterolemia. Endocrinol Metab. 1997; 4: 141-150.

[48] Garvin J, Forman D, Eiseman W, Phillips C. Lowering of human serum cholesterol by an oral hydrophilic colloid. Proc Soc Exp Biol Med. 1965;120:744-746. PMid:5858702 http://dx.doi.org/10.3181/00379727-120-30643

[49] Bock M, Derraik J, Brennan C, Biggs J, Smith G, Cameron-Smith D, Wall C, Cutfield W. Psyllium supplementation in adolescents improves fat distribution and lipid profile: a randomized, participant-blinded, placebo-controlled, crossover trial. PLoS One. 2012; 7(7): e41735. PMid:22848584 http://dx.doi.org/10.1371/journal.pone.0041735

[50] Romero A, Romero J, Galaviz S, Fernandez M. Cookies enriched with psyllium or oat bran lower plasma LDL cholesterol in normal and hypercholesterolemic men from Northern Mexico. J. Am. Coll. Nutr., 1998, 17: 601-608. PMid:9853540 http://dx.doi.org/10.1080/07315724.1998.10718809

[51] Agrawal A, Tandon M, Sharma P. Effect of combining viscous fibre with lovastatin on serum lipids in normal human subjects. Int J Clin Pract. 2007; 61: 1812-1818. PMid:17935545 http://dx.doi.org/10.1111/j.1742-1241.2007.01512.x

[52] Jayaram S, Prasad H, Sovani V, Langade D, Mane P. Randomised study to compare the efficacy and safety of isapgol plus atorvastatin versus atorvastatin alone in subjects with hypercholesterolemia. J Indian Med Assoc. 2007; 105: 142-145. PMid: 17824470

[53] Moreyra A, Wilson A, Koraym A. Effect of combining psyllium fiber with simvastatin in lowering cholesterol. Arch Intern Med. 2005; 165: 1161-1166. PMid:15911730 http://dx.doi.org/10.1001/archinte.165.10.1161

[54] Alberti G, Zimmet P, Shaw J, Grundy S. The IDF Worldwide Definition of the Metabolic Syndrome. International Diabetes Federation, 2006. Available from: http://www.idf.org/metabolic-syndrome

[55] McRorie J, Greenwood-Van Meerveld B, Rudolph C. Characterization of propagating contractions in the proximal colon of ambulatory mini pigs. Dig Dis Sci. 1998(a); 43: 957-963.

[56] Bassotti G, Crowell M, Whitehead W. Contractile activity of the human colon: Lessons from 24 hour studies. Gut. 1993; 34 : 129-133. PMid:8432443 http://dx.doi.org/10.1136/gut.34.1.129

[57] Bassotti G, Germani U, Morelli A. Flatus-related colorectal and anal motor events. Dig. Dis.Sci. 1996; 41: $335-338$. PMid:8601379 http://dx.doi.org/10.1007/BF02093825

[58] Greenwood-Van Meerveld B, Neeley D, Tyler K, Peters L, McRorie J. Comparison of effects on colonic motility and stool characteristics associated with feeding olestra and wheat bran to ambulatory mini-pigs. Digestive Diseases and Sciences, 1999; 44:1282-1287. PMid:10489906 http://dx.doi.org/10.1023/A:1026662610138

[59] McRorie J, Zorich N, Riccardi K, Bishop L, Filloon T, Wason S, Giannella R. Effects of Olestra and sorbitol consumption on objective measurement of diarrhea: impact of stool viscosity on common gastrointestinal symptoms. Reg Tox Pharmacol. 2000; 31: 59-67. PMid:10715225 http://dx.doi.org/10.1006/rtph.1999.1368

[60] Tomlin J, Read N. Laxative properties of indigestible plastic particles. Br Med J. 1988a; 297:1175-1176. PMid:2849492 http://dx.doi.org/10.1136/bmj.297.6657.1175

[61] Riottot M, Sacquet E, Leprince C. Effect of wheat bran upon gastro-intestinal transit in germ-free and conventional rats. Digestion. 1984; 29: 37-41. PMid:6327440 http://dx.doi.org/10.1159/000199006 
[62] Lewis S, Heaton K. Roughage revisited: the effect on intestinal function of inert plastic particles of different sizes and shape. Dig Dis Sci. 1999;44: 744-748. PMid:10219832 http://dx.doi.org/10.1023/A:1026613909403

[63] Tomlin J, Read N. The relation between bacterial degradation of viscous polysaccharides and stool output in human beings. Br J Nutr., 1988b;60:467-475. PMid:3219318 http://dx.doi.org/10.1079/BJN19880119

[64] McRorie J. Clinical Data Support that Psyllium Is Not Fermented in the Gut. Am J Gastroenterol. 2013; 108:1541. PMid:24005363 http://dx.doi.org/10.1038/ajg.2013.211

[65] McRorie J, Pepple S, Rudolph C. Effects of fiber laxatives and calcium docusate on regional water content and viscosity of digesta in the large intestine of the pig. Dig Dis Sci. 1998(b); 43: 738-745.

[66] Washington N, Harris M, Mussellwhite A, Spiller R. Moderation of lactulose-induced diarrhea by psyllium: effects on motility and fermentation. Am J Clin Nutr.1998; 67: 317-321. PMid:9459381

[67] Singh B. Psyllium as a therapeutic and drug delivery agent. Int J Pharm 2007; 334: 1-10. PMid:17329047 http://dx.doi.org/10.1016/j.ijpharm.2007.01.028

[68] Eherer A, Santa Ana C, Fordtran J. Effect of psyllium, calcium polycarbophil, and wheat bran on secretory diarrhea induced by phenolphthalein. Gastroenterology. 1993; 104: 1007-1012. PMid:8385040

[69] Bijkerk C, Muris J, Knottnerus J, Hoes A, De Wit N. Systematic review: the role of different types of fibre in the treatment of irritable bowel syndrome. Aliment Pharmacol Ther. 2004; 19: 245-251. PMid:14984370

http://dx.doi.org/10.1111/j.0269-2813.2004.01862.x 